\title{
Coroamento do Processo de SuCESSÃo da AZALEIa MEdiante UMA O PERAÇÃO DE AQUISIÇÃO
}

\author{
Roberto Minadeo \\ DautoremEngenhania deProdurãopda COPPE/ \\ UFMG, Pesquisador eProfessor dbMestradbem \\ Administraçãoe da FaaldadeNovos Horizontes \\ Professor da Graduaçãoda FaauldadeNovos Hoizontes \\ minadke@yahoocom
}

\section{RESUMO}

A Azaleia se iniciou em 1958, atingindo a posição de uma das maiores produtoras brasileiras de calçados. Com a sucessão, coincidiram os problemas derivados do tripé: a queda das alíquotas de importação de calçados, a maior competitividade do calçado chinês, e a força da moeda brasileira em relação ao dólar. Esses fatores corroeram as vantagens de diversas indústrias, notadamente a de calçados. A aquisição da Azaleia pela Vulcabras representou o coroamento de seu processo sucessório - pois seu fundador tivera uma doença grave, e em seis meses preparou seu sucessor. 0 artigo visa apresentar a trajetória da Azaleia e analisar as causas de sua aquisição pela Vulcabras. Secundariamente, apresenta alguns conceitos sobre empresas familiares e processos de sucessão - com exemplos nacionais. 0 método empregado foi um estudo de caso descritivo e explicativo, apoiado em dados secundários. Concluiu-se que a venda da empresa foi um bem-sucedido coroamento do processo sucessório.

Palavras-chave: Sucessão em Empresas Familiares. G estão de Empresas Familiares. Profissionalização de Empresas Familiares. Fusões e Aquisições. Estratégia Empresarial.

\section{ABSTRACT}

Azalêa beegnin 1958, beeoming thelarget producers of Brazilian footwear. The company faced prodems beeause of: thefall of damand for impated shoes, the competitiveness of Chineseshoemarket and the strengh of the Brazilian ameny. Thesefactors nimed the advantages of varias industries, espeially in fotwear. This artide aims to present thehistory of Azalêa and analyzethecauses of its acquisition byVulcabras Additionally, it shoussomeconceptsabat familybusinesses and successions- with a fennational examples The mothod dhosen for this rearch was a casestudy that is explanatory and descriptive It was conduded that thesale of the business was best way tocontinuethetradition - sincethefoundar hada disese and had six monthstodhooseandpreparea successor; whosemission was to professionalizethe company. Besides the situation of themarke, the sale of the company was the dhice of the company's ouners

Key words: Sucession in FamilyBusinesses Management of FamilyBusinesses Deplyment of Professional Management in FamilyBusinesses MergessandAqquisitions Business strategy. 


\section{INTRODUÇÃO}

Após uma trajetória de acelerado crescimento, a Azaleia se viu surpreendida por um problema típico das empresas familiares: a sucessão, com o falecimento de seu Presidente. D evido ao fato de estar com uma grave doença, pôde ainda preparar seu sucessor; porém, a combinação de dois fatores minou rapidamente as condições competitivas da organização: a fraqueza do dólar em relação ao real e o crescimento das exportações chinesas. Assim, em julho de 2007, a Azaleia foi vendida à Vulcabras. O objetivo do estudo é apresentar a aquisição da Azaleia pela Vulcabras como uma resposta ao quadro vivido pela empresa na fase de perda de seu Presidente - , visando deixar a família menos exposta ao risco de ter grande parte de seu patrimônio em uma companhia cujos riscos passavam a ser inaceitáveis, tendo-se em conta recentes quebras de companhias de grande tradição no setor calçadista.

O artigo está assim organizado: após esta Introdução, a seção 2 apresenta o Referencial Teórico, com quatro subtópicos: a) sucessão em empresas familiares; b) classificação de alguns processos sucessórios em companhias nacionais; c) fusões e aquisições, e d) um breve panorama do setor calçadista. Em função da natureza e das limitações do artigo, pretende-se apresentar ideias norteadoras do estudo nesses temas, sendo impossivel buscar um aprofundamento - que, inclusive, foge do escopo deste estudo de caso. Na Seção 3, apresentam-se os Aspectos Metodológicos adotados. A Seção 4 descreve a Trajetória daAzaleia, com subtópicos sobre a marca O lympikus, o projeto Construindo o Futuro, o processo sucessório, e sua venda. Na Seção 5 é apresentada e analisada a aquisição da Azaleia pela Vulcabras. A Seção 6 traz as Conclusões, com a análise do processo, comentando as possíveis opções estratégicas que a empresa poderia ter escolhido, e analisando a escolha realizada. A seção de Referências encerra o estudo.

\section{REFERENCIAL TEÓ RICO}

\subsection{E mpresas Familiares}

Leone (1992 apudNET O ; MO REIRA JR., 2001) define a empresa familiar como: a) a formação se dá a partir de um membro da família; b) os familiares estão na direção e possuem vínculo com a propriedade; c) os valores do fundador ou da familia devem ser identificados com os do negócio, e d) a sucessão deve estar ligada ao fator hereditário. Para Costa (2006), as empresas familiares apresentam quatro estágios: a) jovem família empresária: período de início e de definição dos papéis dos elementos familiares envolvidos; b) entrada na empresa, onde novas gerações se inserem no negócio; c) trabalho conjunto: procuram-se administrar as complexas relações familiares, e d) passagem do bastão, que trata da resolução do problema da sucessão familiar. Sobre o sucessor, aponta a necessidade de que não deve tentar copiar o fundador, e nem tentar mostrar que tem melhores ideias do que ele.

Davis e Tagun, na década de 80, apresentaram um modelo em Harvard, segundo o qual o principal argumento era que as empresas familiares precisam de uma distinção entre os siste- mas de propriedade e de gestão. G ersick \&al. (1997) criaram 0 Modelo dos três Círculos, que fortalece aideia de que os mais graves dilemas das empresas familiares se relacionam mais com a distinção entre proprietários e gestores do que entre família e gestão como um todo (PIMENTA; BO RGES, 2005). D e acordo com esse modelo, a empresa familiar é representada por três dimensões independentes que se sobrepõem: a gestão, a propriedade e a família (FIG. 1). Segundo Bornholdt (2005), esses termos podem ser substituídos por sistema familiar, societário e empresarial ou apenas família, sociedade e empresa - pois se associa 'propriedade' à ideia de 'dono', sendo que nas empresas familiares tem-se a figura do 'sócio' como um conceito reforçado; e o conceito de gestão remete a cargos de alta gerência. Além disso, os familiares podem ter vários outros papéis dentro da organização, definitivos ou transitórios, estratégicos ou não.

Cada um dos três eixos - propriedade, família e gestão apresenta uma dimensão própria de desenvolvimento (CO STA, 2006). 0 eixo da propriedade se desenvolve em três fases. A primeira se associa ao controlador, por ser uma única pessoa, até porque, quando há sócios, normalmente possuem participações simbólicas. No segundo estágio, dois ou mais familiares dividem o controle. A terceira fase é um consórcio de primos, havendo diversos acionistas, sendo alguns apenas sócios e outros com poder gerencial - além de funcionários profissionais que não são sócios. 0 eixo familiar começa na jovem família empresária, com idade ao redor de 35 anos. A entrada de novas gerações éa segunda etapa do desenvolvimento desse eixo, que provoca o terceiro estágio, ou seja, o trabalho em conjunto. $\mathrm{Na}$ quarta fase, a sucessão, a preocupação principal é a transição do poder. 0 sistema de gestão tem como primeira fase o início da organização, que compreende sua fundação e os primeiros anos; a segunda fase - expansão e formalização - significa a formação de uma estrutura funcional; a fase final, de maturidade, representa a organização, com uma base estável de clientes e rotinas (ESTOL; FERREIRA, 2006).

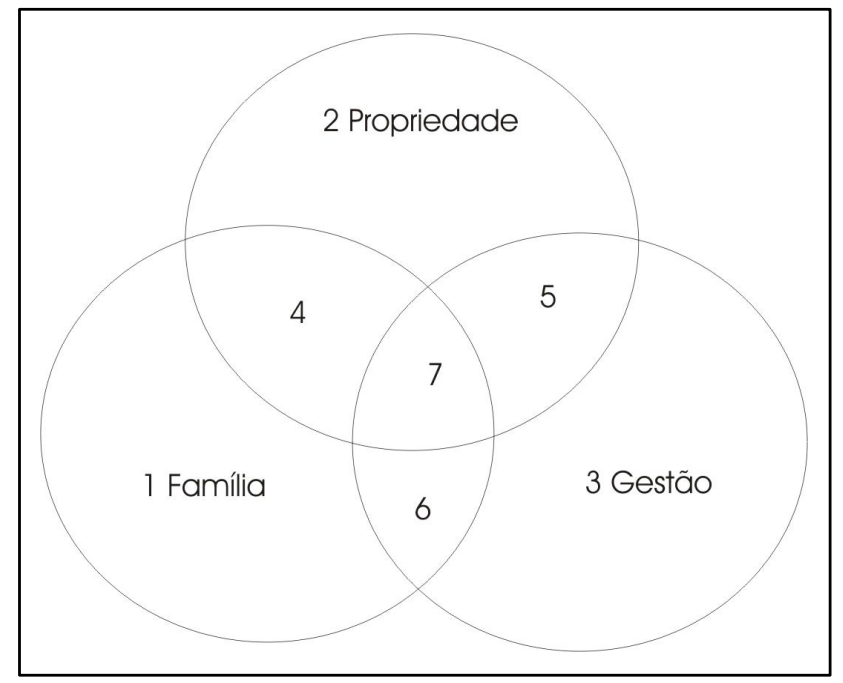

Figura 1: 0 modelo dos três circulos

Fonte: Gersick \& al. (1997, p. 6) 
Todos os membros familiares estão enquadrados em um dos sete setores formados pelos três círculos. 0 modelo permite compreender a empresa familiar everificar a complexidade da relação entre os subsistemas, ao observar a posição ocupada por familiares, proprietários e gestores nos papéis: 1) familiares que não participam na gestão e na propriedade da empresa; 2) proprietários do negócio que não são membros da família e nem participam da administração; 3) gestores que não são familiares nem proprietários, normalmente, profissionais contratados; 4) membros da família proprietários da empresa que não participam de sua gestão; 5) proprietários não-familiares que gerenciam a organização; 6) membros da família que participam da gestão, e 7) grupo formado por familiares que são também proprietários e gestores (COSTA, 2006).

Lodi (1987 apudESTO L; FERREIRA, 2006) aponta três tipos de crises das empresas familiares: a) a sucessão, ou passagem do bastão do fundador para seu sucessor, dado o extremo culto à personalidade e concentração de poder; b) a passagem da segunda à terceira geração coincide com 0 crescimento e a multiplicidade dos negócios, havendo crise de liderança entre diversos familiares, e c) a perda da identidade da empresa, que não mais possui clareza sobre seus objetivos. 0 estudo em tela se trata de uma resolução de uma crise do primeiro tipo, mediante a escolha de um sucessor pelo próprio fundador, que realiza um processo de profissionalização, preparando a empresa para os controladores decidirem o próximo passo.

\subsection{F usões e Aquisições}

Barros \&al. (2003) realizaram uma pesquisa com envio de questionários às 500 maiores empresas nacionais, a respeito de aquisições após 1995, havendo retomo de 196 - das quais, 33\% participaram apenas de processos de aquisição, $6 \%$ apenas de processos de fusão, $15 \%$ de aquisição e de fusão, e $46 \%$ não se envolveram em operações desse tipo. A pesquisa obteve $59 \%$ de respostas sobre motivação da operação com os seguintes fatores: aumento de participação de mercado, aquisição de marcas e penetração em novos mercados. A maior parte das empresas $(44,6 \%)$ foi adquirida em situação financeira precária.

Minadeo (1992) relaciona os seguintes motivos para a compra de uma empresa: i) legal; ii) verticalização; iii) valorização; iv) excesso de capital; v) expansão geográfica; vi) desfazimento de adquiridas; vii) marca; viii) oportunidade; ix) diversificação; $\mathrm{x}$ ) concomênciainternacional; xi) busca de uma equipe gerencial; xii) economia de tempo; xiii) complexidade e automação; xiv) fortalecimento; xv) eliminação de concorrentes; xiv) alcance de novos mercados. As mudanças da economia dos anos 90 são apontadas por Rossetti (2001) como uma das causas que intensificaram as F\&A no Brasil. Fatores que moldaram essa nova estratégia: a) a globalização de mercados; b) a intensificação dos fluxos de investimentos externos; c) a redução dos mecanismos tradicionais de proteção; d) a remoção de barreiras; e) as privatizações, e f) os processos sucessórios em empresas familiares.

O Q uadro 1 apresenta algumas empresas que realizaram F\&A, bem como as motivações subjacentes dessas operações. $\mathrm{O}$ Q uadro 2 mostra algumas F\&A problemáticas.

As situações do Q uadro 2 ilustram que as F\&A não representam uma solução universal aos problemas empresariais. Porém, ao constatar operações malsucedidas, também cabe observar que alguns importantes fatores que teriam levado ao seu sucesso não foram observados.

\begin{tabular}{|c|c|c|c|c|}
\hline Adquirente & Adquirida & Ano & Objetivos / Vantagens & Fonte \\
\hline Royal Ahold & Giant & 1980 & \multirow{3}{*}{$\begin{array}{l}\text { Aquisições pioneiras de varejistas norte-americanos por grupos } \\
\text { estrangeiros, visando ingressar nesse mercado. }\end{array}$} & \multirow{3}{*}{\begin{tabular}{|l|} 
Kerin e \\
Varaiya \\
(1985)
\end{tabular}} \\
\hline Promodès & Houchens & 1983 & & \\
\hline Tengelman & $\mathrm{A} \& \mathrm{P}$ & 1983 & & \\
\hline Sainsbury & Shaw's & 1987 & Ingresso nos EUA. & \multirow{2}{*}{$\begin{array}{l}\text { Wrigley } \\
(2000)\end{array}$} \\
\hline Royal Ahold & Stop \& Shop & 1996 & Ampliação da atuação nos EUA. & \\
\hline \multirow{3}{*}{ Casas Bahia } & Fin. Intervest & 1970 & \multirow{3}{*}{$\begin{array}{l}\text { A compra de uma financeira propiciou condições ao varejista de } \\
\text { ampliar o crédito ao consumidor. } \\
\text { O portunidade de verticalização, visando baixar os preços. }\end{array}$} & \multirow{3}{*}{$\begin{array}{l}\text { Costa e } \\
\text { Garcia } \\
(2006)\end{array}$} \\
\hline & Fin. Símbolo & & & \\
\hline & $\begin{array}{l}\text { Móveis Bartira e } \\
\text { Bela Vista }\end{array}$ & $\begin{array}{l}\text { Anos } \\
80\end{array}$ & & \\
\hline Petrobras & Perez Companc & 2002 & $\begin{array}{l}\text { Assumir a liderança na América Latina. Com a aquisição, } 80 \% \text { das } \\
\text { receitas internacionais da Petrobras passam a ser provenientes do } \\
\text { Cone Sul. }\end{array}$ & \begin{tabular}{|l|} 
Ribeiro e \\
Júnior \\
$(2007)$ \\
\end{tabular} \\
\hline $\begin{array}{l}\text { Votorantim e } \\
\text { Suzano }\end{array}$ & Ripasa & 2004 & $\begin{array}{l}\text { Impedir o ingresso da Stora Enso no Brasil, oferecendo um valor } \\
\text { superior pela Ripasa. }\end{array}$ & \begin{tabular}{|l|} 
Perera $\notin$ al. \\
$(2007)$
\end{tabular} \\
\hline \multirow{2}{*}{$\begin{array}{l}\text { Procter \& } \\
\text { Gamble }\end{array}$} & Gillette & 2005 & $\begin{array}{l}\text { Ingressou em um mercado em que atuava pouco, formado pelo } \\
\text { público masculino. Além disso, em relação à publicidade, passou a } \\
\text { conviver com uma nova realidade: o uso de celebridades, praticado } \\
\text { pela Gillette, e desconhecido por ela. }\end{array}$ & $\begin{array}{l}\text { 'Am- } \\
\text { brosio } \\
(2007 a)\end{array}$ \\
\hline & $\begin{array}{l}\text { Fabricante } \\
\text { britânico de } \\
\text { sabonetes }\end{array}$ & 1930 & A té então, estava atuando apenas nos EUA e no Canadá. & Jones (2002) \\
\hline
\end{tabular}

Q uadro 1: Empresas que utilizam de Fusões e Aquisições e seus objetivos pretendidos

Fonte: Elaborado pelos autores, com base nos dados da pesquisa. 
Em 1993, a Quaker comprou a Snapple por US\$ 1,7 bilhỏes. Quatro anos depois, a Snapple foi revendida por US\$ 300 milhões. A ssim, no ano 2000, a Pepsi adquiriu a Q uaker (DEIG HTON, 2002).

A Pharmacia e a Upjohn se fundiram em 1995, porém, nunca houve integração das atividades. A Pharmacia buscava distribuição nos EUA, enquanto que a Upjohn estava carecendo de novos produtos em desenvolvimento. A fusão em nada resolveu esses pontos (KANTER e D RETLER, 1998; ROBERT, 1998).

Em maio de 2007, a Daimler encerrou a mal-sucedida aquisição da Chrysler, feita 9 anos antes. A DaimlerChrysler injetou US\$ 675 milhões na Chrysler para a Cerberus adquiri-la, levando junto cerca de US\$ 18 bilhões de dívidas junto a planos de pensão (EDMONSON, 2007).

No ano 2000, a Pharmacia \& Upjohn e a Monsanto se fundiram, porém, o negócio foi desfeito devido à falta de sinergias entre a Monsanto e uma produtora de medicamentos (FOSTER; KAPLAN, 2002).

Em 1982, a Bendix compra a Martin Marietta, que tentou comprar a Bendix com apoio da United Technologies. A situação apenas interessou aos bancos, pois ambas se endividaram para a operação. Em 1983, a Bendix Corp. foi adquirida pela Allied Corp., e a Martin Marietta permaneceu independente (AAKER, 1998).

Em 1968, a General Foods adquire a Burger Chef - rede de fastfoolcom 700 lojas. A operação foi uma resposta à proibição imposta pela Federal Trade Commission a que a $\mathrm{G}$ eneral Foods adquirisse empresas que vendessem a supermercados. Porém, apenas em 1972, a Burger Chef teve prejuízos de US\$ 83 milhões (AAKER, 1998).

A McKinsey comprou a ICG (da área de Tecnologia da Informação), em 1989, mas a maior parte dos 200 funcionários da adquinida foi embora (SVEIBY, 1998).

Nos anos 80, a agência de propaganda Saatchi \& Saatchi adquiriu empresas de consultorias, relações públicas e de apoio, tendo sete anos de prejuízos, e vendendo várias adquiridas (ZO OK eALLEN, 2001; RO SENBUSH, 2007).

Nos anos 80, a cervejaria Anheuser-Busch adquinu a Eagle Snacks, vendida na década seguinte à Frito-Lay, após cerca de US\$ 120 milhões em prejuízos, pois a sinergia entre cerveja e salgadinhos não se materializou, apesar de o consumo desses itens poder ser simultâneo em muitos casos (ZOOK e ALLEN, 2001; ROSENBUSH, 2007).

A Mattel ingressou em software, adquirindo a The Learning Co., da área tecnológica, por US\$ 3,8 bilhões em 1999, revendida em poucos anos, após grandes prejuízos, que quase custaram a sobrevivência da empresa, e a saída de seu Presidente, Jill Barad (ZO OK e ALLEN, 2001; RO SENBUSH, 2007).

Q uadro 2: F\&A Problemáticas.

Fonte: Elaborado pelos autores, com base nos dados da pesquisa.

\section{ASPECTOSMETODOLÓGICOS}

O discurso epistemológico é uma reflexão sobre os pressupostos da ciência, com o fim de evidenciar os métodos utilizados e propiciar validade desse conhecimento através de um estudo crítico e descritivo dos princípios, do processo e dos resultados obtidos (DIÓ GENES, 2007). Assim, esta pesquisa pode ser classificada como descritivae explicativa, com enfoque qualitativo, visto que teve como objetivos: contextualizar, descrever e analisar a trajetória da Azaleia até seu processo sucessório e a sua aquisição.

Quanto ao método, trata-se de um estudo de caso. Segundo Gil (1987), a profundidade e o detalhamento de informações obtidas pelo estudo de caso são praticamente impossíveis de ser obtidos mediante algum outro método. Martins (2006) aponta que um estudo de caso deve ser: a) importante, por apontar um recorte engenhoso de uma situação complexa da vida real; b) eficaz, por enunciar com detalhes o protocolo que orientou o estudo, e c) suficiente, pelo fato de que as fronteiras entre o fenômeno em estudo e o seu contexto estão claramente delimitadas, evitando-se interpretações e descrições indevidas ou não contempladas pelo estudo. A intensificação do uso da técnica de estudos de caso em pesquisa é importante no auxílio das explicações dos motivos de sucesso ou fracasso de organizações, propiciando bases para a aplicação em situações reais de concorrência (SERRA; CO STA; FERREIRA, 2007). Mais especificamente, trata-se de um estudo de caso explicativo - que procura justificar causas, esclarecer fatores que contribuí- ram a determinado fenômeno. Nos estudos de caso explicativos as questões mais adequadas são "como?" e "por quê?" (VERGARA, 1997; YIN, 2005). As questões relevantes se referem aos motivos da venda da Azaleia pela família controladora.

Y in (2005) aponta seis fontes de evidências como as mais usuais nesses estudos: a) documentos; b) registros em arquivos - normalmente digitais; c) entrevistas; d) observações diretas; e) observação participante, ef) artefatos físicos ou culturais, como aparelhos, equipamentos, ferramentas ou obras de arte - que podem fornecer evidências físicas. 0 autor aduz três princípios para a coleta de dados: a) usar várias fontes de evidência; b) criar um banco de dados para 0 estudo de caso, e c) manter 0 encadeamento de evidências. $\mathrm{O}$ estudo utilizou: a) pesquisa documental; b) registros de artigos acadêmicos: sobre a empresa estudada, sobre sucessão, a respeito do setor calçadista, apontando alguns estudos de casos de outras companhias, e c) observação direta: a Vulcabras foi uma das cinco empresas analisadas diretamente na Dissertação de Mestrado do autor - mediante visita à fábrica e aplicação de um questionário semiestruturado.

\section{ESTUDO DO PROCESSO DE SUCESSÃO DA AZALEIA}

\subsection{Contextualização}

\subsection{A presentação de alguns processos sucessórios de em- presas nacionais}

Minadeo (2008) classificou e analisou processos sucessórios, divididos em 20 fatores. Constatou a existência de inú- 
meras razões que levam à sucessão, como: a) o crescente dinamismo empresarial; b) o maior ritmo de mudanças no setor empresarial, ec) a realidade da empregabilidade - que costuma trazer ofertas melhores aos gestores com bom desempenho, visibilidade e uma carreira promissora como o potencial de Presidente em alguma outra companhia.

Os quadros 3, 4 e 5 abaixo, refletem, respectivamente: processos planejados; emergenciais e problemáticos. A finalidade - longe de esgotar as categorias ou situações de cada uma delas - é apontar uma variedade de situações: empresas que já possuem uma cultura de planejar o processo sucessório, mostrar problemas quando o mesmo não existe, e ilustrar algumas situações imprevistas que exigem a existência de planos contingenciais ou que foram fontes de problemas diversos.

O Pão de Açúcar foi criado ao final dos anos 50, por Valentim Diniz. Desde 0 ano de 1953, já fora aberto 0 Supermercado Americano, porém, vendido em 1959. A abertura do primeiro supermercado Pão de Açúcar coincidiu com a fo matura de seu primogênito, A bilio Diniz, em administração de empresas, pela FGV, indo depois estagiar em supermercados na França e nos EUA, auxilian do a ampliação do negócio (MARCOVITCH, 2008).

Cassio Casseb foi sucedido na Presidência do Pão de Açúcar pelo consultor Claudio G aleazzi. Além de equilibrar os custos do grupo, Galeazzi deveria formar o próximo presidente - em cerca de dois anos (MANO, 2007).

A Receita Federal encontrou irregularidades na Schincariol em 2003, ocorrendo nesse ano a morte do presidente, substituído por seu filho Adriano. Em 2007, encerrou-se o processo de profissionalização. 0 último membro da família atuante na gestão passou ao Conselho. Foram adquiridas novas marcas para evitar a dependência da Nova Schin. A lém disso, foram adquiridos novos centro s de distribuição (D 'AMBRO SIO, 2007b; ONA GA, 2007).

Foi criada a D ramd, uma hddng para administrar o patrimônio dos cinco filhos do fundador da Randon, sendo que apenas um deles, pediatra, não atua no grupo (SPOTO RNO, 2007).

Sergio Andrade e Roberto Gutierrez criaram a Andrade Gutierrez em 1948. Sergio sempre foi ativo na companhia, Gutierrez teve outros negócios. Ambos inspiraram a diversificação, deflagrada em 2000. Em 2007, Sérgio deixou o comando da AG S.A., passando ao Conselho, sendo sucedido por 0 távio Marques de Azevedo - vindo da Telebrás, e que ingressara em 1992, sendo um dos mento res do consórcio que arrematou a Telemar. Sérgio Andrade comand ava a holdingdesde a criação, em 2000 (MAGALHÃES, 2007).

Em 1992, Jo sé Martins Pinheiro Neto contratou uma consultoria especializada em escritó rios de advocacia para um diagnóstico do escritório que leva seu sobrenome. Inicio u-se a sucessão, pois tudo girava em torno dele. Um triunvirato assumiu, a seu lado. Nos anos $90,80 \%$ das açõ es estavam nas mãos de 9 sócios. Os outros 20\% eram detidos por 16 pesso as. Em 2007, nenhum dos 68 sócios detinha mais de $2 \%$ do capital. A média de idade dos sócios era de 38 anos. 0 escritório somava 10 mil casos em e 1,4 mil clientes ativos. Também nesse ano, o escritório definiu que a venda de cotas e a promoção de novos sócios devem ser anuais. $O$ escritório tem por tradição transformar estagiários em sócios, a mudança é que certas ações foram institucionalizadas. 0 peso dos votos dos sócios passou a ser igual, independentemente do número de cotas detidas. Foram criadas regras mais claras de apo sentadoria: sócios e funcionários são obrigados a sair aos 65 anos. Aos 60, eles já com eçam a abrir mão das ações (CA NÇADO , 2007).

Renato Barcellos Guimarães, com 47 anos, foi o primeiro de fora da família Leão a assumir a fabricante centenária Mate Leão, assumindo em 2005. D o is anos depois, a empresa foi vendida à Coca-Cola (LIMA , 2007).

Hans Stern criou a rede de joalherias H. Stern nos anos 40, e deixou a direção executiva em 1995 ao seu filho mais velho, Roberto, passando à Presidência do Conselho, porém, sem deixar de acompanhar os negócios. Ao falecer, em 2007, a empresa por ele criada era das quatro maiores redes mundiais do setor, com 160 lojas em 12 países, sendo presidida por um executivo, Richard Barczinski (MA GALHÃES, 2007).

O grupo Algar promoveu uma reestruturação, pela qual os familiares deixaram de ser gestores. Porém, nos anos 90, o grupo estava endividado, e criaram-se regras para os familiares voltarem à gestão: formação acadêmica com mestrado e 5 anos de experiência em empresas de fora. A familia teve a participação de consultores externos, para viabilizar o ingresso de membros da terceira geração. Criou-se o conselho da familia, que se reúne a cada 3 meses, cujo papel é paralelo ao dos Conselhos de Administração das S.A. (BALARIN, 2007).

Amador Aguiar fez uma sucessão bem-sucedida no Bradesco: em 1980 passou a Presidência a Lázaro Brandão, recolhendo-se ao Conselho, e apenas falando se solicitado. Na sucessão seguinte, Brandão promoveu todos os vice-presidentes ao Conselho, deixando o caminho livre a Márcio Cypriano (CA MARG OS, 2007).

Jorge Johannpeter presidiu o grupo Gerdau por 23 anos, transformando-a de nacional a um grupo presente em 13 países. A transição a seu filho André Johannpeter foi em 2007. O processo sucessório foi auxiliado por 3 consultorias e dois professores. 0 filho mais velho de Jorge, Carlos, saíra do grupo. André começara a trabalhar aos 16 anos, tendo cursado administração, destacando-se entre 2002-6 na filial dos EUA. Após o anúncio do novo Presidente, foi preparada uma reestruturação, com novos membros ingressando no comitê executivo, no lugar de Jorge Gerdau, Frederico Gerdau e de Carlos Petry - que foram ao Conselho. Além disso, a empresa decidiu passar a ter um Presidente (CEO), André, mais focado na área externa e nos planos de crescimento; e um Chief OperativeOfficr (CO O), mais focado no o peracional, sendo escolhido um primo seu, Cláudio, praticamente da mesma id ade. Nos primeiros meses na Presidência, André viajou muito, para supervisionar pessoalmente as principais aquisições - havendo uma equipe analisando cada oportunidade. Finalmente, o novo comitê executivo, formado por sete pessoas, se reúne quinzenalmente, tocando a estratégia em sintonia com o Conselho, aprimorando as técnicas de Governança Corporativa (NAIDITCH, 2007; REESTRUTURA ÇÃO NA..., 2007).

Quadro 3: Processos sucessórios planejados de empresas nacionais

Fonte: Elaborado pelos autores. $\int$ CONTEXTUS Revista Contemporânea de Economia e Gestão. Vol.8 - № 1 - jan/ jun/ 2010. (57-70). 
Em 2008, José Vicente Marino saiu da Presidência da filial brasileira da Jonhson \& Jonhson para a vice-presidência de marketing da Natura; sendo substituída por Suzan Rivetti, na J\&J havia mais de vinte anos, e que era a mais cotada, em função de a empresa valorizar seu pessoal (D'AMBROSIO, 2008; MEYER, 2008a; MEY ER, 2008b).

Em 2008, Luiz Femando Furlan, ex-ministro, retomou à Presidência do Conselho de Administração da Sadia em um momento crítico, pois a empresa perdera cerca de $\mathrm{R} \$ 700$ milhões em função de aplicações financeiras e à elevação do dólar (WALTER..., 2008).

O último filme que Adhemar Gonzaga dirigiu encemou o ciclo da Cinédia: Salário Mínimo, comédia com Paulo G racindo, Renata Fronzi e Costinha, juulgado um fracasso pelo próprio produtor. Alice Gonzaga assumiu a direção, em 1971, organizou o acervo, e preocupou-se em alugar os estúdios em caráter mais profissional. Em 1975, a Globo filmou ali a série Sítio do Picapau Amarelo. Algumas agências publicitárias começaram a usar os estúdios em 1979. Cacá Diegues usou a locação em 1990, para fazer Dias Melhores Virão. No ano 2000, a Globo deixou de alugar esses estúdios da Cinédia, mudando-se definitivamente para o Projac (GIRION, 2001).

Q uadro 4: Processos sucessórios emergenciais de empresas nacionais

Fonte: Elaborado pelos autores.

\begin{abstract}
A UNIPAR apresenta um conturbado histórico de sucessão, desde os anos 80. Foi criada por Alberto Soares Sampaio, e cresceu na gestão do genro Paulo Geyer, que faleceu em 2004. A direção da empresa passou pela esposa de Paulo Geyer e quase todos os filhos. A alternância de poder foi turbulenta - a tal ponto que o casal doou suas obras de arte ao Museu Imperial, de modo que ficassem de fora das disputas familiares (GASPAR, 2007).

Sílvio Santos procurou o consultor Bernhoeft para tratar do problema sucessóno do SBT em 2001, após o seqüestro da filha. $\mathrm{O}$ consultor fez as três clássicas perguntas: 0 que espera de cada filho, o que pensa so bre o futuro de cada um deles, e como imagina o futuro das empresas. Sílvio Santos não soube responder a nenhuma delas. Bernhoeft conclui que para ele a empresa não pode existir sem ele. Todas as empresas do grupo tiveram lucro em 2006, menos a TV - diretamente gerida por Sílvio Santos (SO BRAL, 2007).

Em 1987, a Presidência da Perdigão passou do fundador Saul Brandalise a seu filho Flávio; o fundador passou ao Conselho. O utro filho, Saul Jr., passou a responder pela recém criada Perdigão Agropecuária, que concentrava a produção. 0 fundador nunca se preocupara com a sucessão, conceitos de gestão, ou uma recessão. Em 1985, contratara Ivan Bonato, cunhado de Saul Jr., para iniciar a profissionalização. Em 1989, Saul Jr. passou à vice-presidência da holdng e Bonato assumiu a vicepresidência. Em 1990, o grupo começou a vender ativos, e a reduzir as despesas. Porém, os resultados eram fracos. Em 1993, a Presidência do Conselho passou a João Eggon da Silva, que depois também assumiu a Presidência. Em 1994 a empresa foi vendida a um grupo de fundos de pensão. Em 1995 a Presidência passa a Nildemar Secches, que fez cortes drásticos (ULLER, 2002).

Cássio Casseb deixou a Presidência do Pão de Açúcar após quase 2 anos, por desempenho abaixo do esperado. Casseb se empenhou em cortar custos, mas em sua gestão, a rede perdeu a liderança ao Camefour. A geração de caixa caiu 2,5\% em 5 anos. Abílio Diniz na prática atua como Presidente. Em 2006, teve a pior rentabilidade dos últimos 8 anos. No primeiro trimestre de 2007, ela foi ainda pior: 6,6\% (DANTAS e RACY, 2007; MANO , 2007).

A Casas Pernambucanas era a maior rede varejista do Brasil nos anos 70, porém, com a morte do fundador, os herdeiros começaram a brigar, e a rede entrou em decadência (NÓ BREGA, 2007).
\end{abstract}

Q uadro 5: Processos sucessórios problemáticos de empresas nacionais

Fonte: Elaborado pelos autores.

\subsection{Indústria Calçadista $\mathrm{N}$ acional}

Rocha eViana (2006) apontam os seguintes aspectos positivos que podem melhorar a competitividade da indústria de calçados: a) é um produto de primeira necessidade para a população; b) o Brasil é um dos raros países que possuem tanto uma indústria de calçados e uma de couros, ambas atendendo aos mercados doméstico e externo; c) o mercado mundial de calçados tem se expandido; d) o mercado interno apresentou, nos últimos anos, um aumento do consumo percapita, e e) a existência de aglomerados de empresas nos maiores polos produtores brasileiros, contribui para o aumento da eficiência e a redução dos custos de produção e logística. Aduzem aspectos negativos da indústria de calçados brasileira e nordestina: a) dependência de incentivos fiscais na Região Nordeste; b) alto custo de transporte; c) valonização do real em relação ao dólar; d) aumento da carga tributária; e) dificuldade das empresas brasileiras em fixar marca própria no mercado internacional; f) forte concorrência da China. Em relação a essa última dificuldade, Alves e Filho (2005) afirmam que de 1993 a 1995 as importações brasileiras de calçados passaram de US \$ 41,1 milhões para US \$ 195,2 milhões.

A afirmação de Rocha e Viana (2006), ligada aos incentivos fiscais, parece desconhecer que inúmeros setores de vários Estados utilizaram estratégias semelhantes. A vinda da Fiat para Minas pode ser considerada um divisor de águas: a) a primeira montadora fora do $\mathrm{ABC}$; b) em uma região sem indústrias de autopeças, ec) mais distante dos principais polos consumidores: São Paulo e Rio de Janeiro. Porém, em poucos anos, os efeitos da fábrica mineira da Fiat para o Estado de Minas $\mathrm{G}$ erais passaram a ser tão notáveis que, com a abertura 
dos anos 90, inúmeros outros Estados fizeram esforços apreciáveis no sentido de atrair novas montadoras: Bahia, Goiás, Paraná, Rio de Janeiro, Rio Grande do Sul e São Paulo foram bem-sucedidos na atração de novas fábricas.

O Polo Calçadista da Bahia - apesar de criado nosanos 60 apenas se consolidou com grandes fábricas nos anos 90 , sendo a Azaleia uma das pioneiras, instalando-se em Itapetinga e criando cerca de 8 mil empregos. Alpargatas, Agabê, Pé de Ferro eAzaleia anunciaram planos de expansão no Nordeste, em detrimento de suas operações no Sul e Sudeste (RO CHA;VIANA, 2006).

Cabe aduzir que, apesar de 0 setor calçadista ser um mercado maduro, ainda há espaço para inovações. Assim, em 1989, enquanto caminhava sob o sol, um italiano, Polegato, fez buracos nas solas de seus tênis - dado que seus pés estavam muito suados. Isso o inspirou a projetar um sapato que respirasse; depois de tentar sem sucesso vender a ideia a algumas marcas, criou a $\mathrm{G} \mathrm{eox}$ em 1995, primeiro com calçados infantis, ingressando depois nos segmentos de calçados e roupas para adultos. Vendeu 21 milhões de pares de sapatos em 2007, aumentando suas receitas em 26\% sobre 2006, para US\$1,2 bilhão, com lucros de US\$ 193 milhões. A G eox conseguiu clientes em várias partes do mundo, com seus sapatos que respiram. No Brasil, fez uma parceria com a Paquetá para a produção de sapatos com sua marca (SCHENKER, 2008).

\subsection{T rajetória da Azaleia e fase de crescimento durante a gestão do fundador}

Nestor Herculano de Paula, Arnaldo Luiz de Paula, Nelson Lauck, Arlindo Lauck e Theno Berlitz começaram a produzir calçados em 1958, com as marcas Laika e Néctar. Em 1965, veio a Azaleia. Nestor - com experiência em uma fábrica de móveis - entrou na sociedade com os recursos da venda de uma casa recebida em herança (RIBEIRO, 2003). As receitas da Azaleia subiram de R\$ 272 milhões em 1992 para R\$ 539 milhões em 1996. No período, a rentabilidade passou de R\$ 12 para R $\$ 61$ milhões. Após um processo de 5 anos, a empresa passou a vender $100 \%$ de produtos com suas próprias marcas. A empresa contava com 20 franqueados no Chile (MATURO, 2004), e adotou o modelo de lojas que só vendem produtos da marca - com as bandeiras Azaleia e Olympikus. 0 Chile era 0 principal mercado, ao lado de: Peru, Colômbia, México e Rep. Checa (CAETANO, 1997; D 'AMBRO SIO, 2005).

\subsubsection{A marca Olympikus}

A marca O lympikus foi criada em 1975, para contomar o problema da sazonalidade do calçado feminino. Começou com sapatos para colegiais, focados na prática da educação física, que se tornara obrigatória. Foi descontinuada em 1989, pois os tênis vulcanizados estavam obsoletos, em função das solas injetadas em poliuretano. D iversos investimentos em projeto, produção e gestão foram realizados. A marca voltou a ser alvo de campanhas publicitárias em 1994 - após três anos com apenas um produto sendo comercializado. E, em apenas dois anos, a marca O lympikus chegou à posição de maior marca de tênis no Brasil no ano anterior, em receitas, com um valor de cerca de $\mathrm{R} \$$
250 milhões, correspondente à metade do faturamento da Azaleia, obtidos com a venda de quase oito milhões de pares. Em 1996, a Azaleia criou uma nova divisão, Olympikus Prosports, do setor de agasalhos esportivos, meias, bolsas e bonés, lançando cerca de 70 produtos, projetados por um estúdio de New York e produzidos por fábricas do Rio de Janeiro e de São Paulo (CAETANO, 1997).

\subsubsection{Projeto Construindo o Futuro}

Segundo Bernardi (1997), em 1991, a empresa promoveu uma pesquisa interna a fim de descobrir de que seus quase dez mil funcionários mais precisavam. As principais respostas foram dos seguintes itens: saúde, casa própria, educação, transporte e segurança. A empresa descobriu que mais de dois terços de seus funcionários haviam estudado muito pouco; assim, contratou Emest Sarlet, filósofo e sociólogo, que idealizou o projeto Azaleia Construindo o Futuro, lançado em 2001.0 projeto foi inspirado no fato de o maior fabricante de calçados do mundo, a Bata, afimar que o seu crescimento deveu-se a ter criado um colégio para capacitar seu pessoal em 1925. No início dosanos 70, a Bata era uma das companhias mais internacionais do mundo, operando em 73 países. A Bata, nascida no que era aTchecoslováquia, foi nacionalizada. $O$ filho do fundador criou uma nova empresa no Canadá, que, antes da II Guerra, já detinha fábricas naÁfrica e Ásia, liderando a produção mundial de calçados. Nos anos 90, contava com cerca de 80 fábricas, sendo a maior parte na Ásiae A frica, e uma na França, para testar novas técnicas gerenciais. A Bata abriu o caminho para outros, como a Nike, cerca de 40 anos depois, pois esta cresceu sem produzir nada, fazendo toda a sua produção na Ásia (CALORI đal., 2000).

A Azaleia passou a ter planos de saúde, habitação, educação e transporte para os funcionários e familiares. A empresa criou diversos centros de educação, tradicionais, profissionalizantes e de idiomas. Em função do programa, 0 índice de retrabalho baixou de dois para quase zero em mil pares; a rotatividade caiu de 0,7\% para 0,5\% e 0 absenteísmo foi reduzido à metade (BERNARDI, 1997). A Azaleia passou a custear $80 \%$ da despesa de até duas disciplinas dos funcionários em universidades - com 260 funcionários usando esse benefício. Além disso, passou a oferecer refeições aos que trabalham e também estudam. Criou uma creche para 800 crianças, operando $24 \mathrm{~h} / \mathrm{dia}$. Depois da creche, o Centro de D esenvolvimento Educacional atende os alunos até os 14 anos. Aos 16 anos, os filhos dos funcionários podem entrar no Centro de D esenvolvimento Profissional, e, em um ano, com bolsa do CNPq, tornam-se sapateiros profissionais. Também foi criado um plano de participação nos resultados, ligado às metas: em 1996, a empresa distribuiu R 14 milhões, e os funcionários ganharam 17 salários. Os investimentos sociais foram da casa de $\mathrm{R} \$ 65$ milhões em 2001 - cerca de 10\% da receita do ano. Em 2003, a empresa respondeu por $68 \%$ da renda dos 50 mil habitantes de Parobé (G O MES, 1997). Para Ribeiro (2003), a Azaleia é uma organização com potencial na esfera social, em virtude de seu exercício no campo da Responsabilidade Social; o projeto Construindo o Futuro nada mais é do que uma ação de Relações Públicas. 


\subsection{Sucessão, T ransição e Venda da Azaleia}

No início de 2004, falece o fundador da Azaleia, Nestor Herculano de Paula, aos 66 anos. Além de participar de diversas entidades empresariais, entre 1998 e 2001, presidira a Associação Brasileira das Indústrias de Calçados - ABIC. A Presidência passou a Antônio Britto, ex-governador gaúcho (1995-1998), contratado pelo próprio fundador, seis meses antes, pois Nestor já estava com câncer, e preparou a própria sucessão. Britto, enquanto G overnador, fez o acordo que trouxe uma fábrica da GM em G ravataí, além de lideraralguns processos de privatização. Segundo Naiditch (2004), Britto se aproximara daAzaleia em 1999, como consultor da ABIC. Aduz que a empresa já fizera uma tentativa de sucessão, ao contratar Gumercindo Neto, no ano 2000; porém, esse especialista em marketing foi contratado para a rival Alpargatas. Acrescenta que a primeira tarefa do novo Presidente foi uma descentralização, pois o fundador e condutor da empresa durante cerca de 40 anos era centralizador, e os planos estratégicos estavam apenas em sua cabeça.

0 fato de ser centralizadoré ilustrado pela ocorrência de que tanto o sucessor quanto o outro profissional contratado para essa tarefa vieram de fora da empresa. $\mathrm{O} u$ seja, o fundador não soube criar nos quadros da sua empresa alguém que viesse a sucedê-lo, apesar do forte investimento em treinamento de pessoal em geral e dos executivos em particular. Seu estilo de gestão também seguiu a caracteństica oneman showque não permite 0 surgimento de outras lideranças à sua volta, ao mesmo tempo em que está frequentemente em evidência na imprensa, inclusive com vários anúncios de planos mirabolantes e que não vieram a se materializar.

Em 2004, a Azaleia abriu uma fábrica em Sergipe. D e sua produção total, $50 \%$ já provinham do Nordeste. Nesse ano, a Azaleia produziu 35,6 milhões de pares, 11,9\% a mais do que no ano anterior. A receita bruta atingiu R $\$ 992,4$ milhões, crescendo 19,8\% sobre 0 ano anterior. 0 lucro líquido subiu 71,7\% - chegando a R\$17 milhões. Em 2005, a Azaleia inaugurou a unidade de Itororó e ampliou 13 das 18 fábricas que possuía na Bahia. Ainda nesse ano, a empresa fechou a fábrica de São Sebastião do Caí, no Rio Grande do Sul, demitindo os 800 funcionários. A unidade produzia onze mil pares/dia do tênis O lympikus. A Azaleia contava com 28 fábricas, sendo 5 no Rio $\mathrm{G}$ rande do Sul, 18 na Bahia e 5 em Sergipe, com capacidade de 170 mil pares/ dia. A Azaleia vendeu a Energética Campos de Cima da Serra, com participações em 5 hidrelétricas, por R $\$ 21$ milhões (BUENO, 2005a, BUENO, 2005b, BUENO, 2005c, NAKAMURA, 2007).

As receitas da Azaleia em 2005 foram de cerca de $\mathrm{R} \$ 1$ bilhão - crescendo 1,8\% em relação ao ano anterior, e com lucros de R \$ 27,7 milhões. Foram vendidos 24,9 milhões de pares no mercado interno e exportados 6,6 milhões de pares. As exportações caíram 15,4\% em valor e 25,8\% em volume. Enfim, o período de transição da empresa após a passagem da direção do fundador a um profissional foi crítico, agravado pelas dificuldades com o câmbio; porém, a empresa soube fazer ajustes, de modo a conter os custos (BARO NE, 2006). A Azaleia alugou fábricas em Dong Huan, polo chinês, para produzir calçados, vendidos nos EUA e no Brasil (CUNHA, 2005).
Em 2006, fechou umafábrica em Itaporanga D 'Ajuda (Sergipe), com 230 demissões (GÓ MEZ, 2007).

A Azaleia entrou em um novo nicho de mercado, lançando a A/ Z, uma grife mais sofisticada; enquanto os preços dos calçados Azaleia eram vendidos entre R $\$ 39$ e R \$ 69, os produtos da nova marca estavam previstos para chegarem ao mercado com preços entre $\mathrm{R} \$ 59$ e R $\$ 129$. Foi a quarta nova linha criada em dois anos. A primeira delas foi a Funny - de calçados e acessórios voltados ao público pré-adolescente. A segunda foi a sandália Belíssima, uma licença da novela da G lobo de igual nome. Em 2006, foi lançada a linha OLK - marca de roupas e acessórios casuais da marca Olympikus. Além dessas marcas, a empresa era licenciada da Asics e Dijean (BARO NE, 2006).

Antônio Britto renunciou à Presidência, por julgar encerrada a etapa de transição. Adelino Colombo, que presidia o Conselho de Administração e que criara a rede varejista com seu nome, assumiu interinamente. A Azaleia tivera um ano ruim: lucrou $\mathrm{R} \$ 65,4$ milhões em 2006, com receitas de $\mathrm{R} \$ 982,9 \mathrm{mi}-$ lhões, uma queda de 2,7\% ante 2005. A produção alcançou 29,39 milhões de pares, volume 8,8\% inferior à de 2005. As exportações foram de 4,4 milhões de pares, 33\% a menos que as do ano anterior; as receitas com exportações caíram 24,5\%, paraUS $\$ 36$ milhões. 0 endividamento em 2006 subiu de $\mathrm{R} \$ 96,7$ milhões para R 141 milhões (BUENO, 2006; NAKAMURA, 2007).

\section{AQUISIÇÃO DA AZALEIA PELA VULCABRAS}

A Vulcabras foi criada em 1932 na capital paulista; mudou-se para Jundiaí em 1954, e ganhou novo impulso com a contratação do técnico Joseph Pfulg, à época trabalhando no Senegal para a Bata. Em 1974, Pfulg chegou à Presidência - ano em que obteve seu primeiro licenciamento valioso: a Adidas. Em 1979, foi a primeira empresa brasileira a ter calçados de segurança aprovados pelo Instituto de Pesquisas de Pirmasens, na Alemanha, atendendo à Norma DIN 4843, partes 1 e 2. Em 1981, iniciou a produção em Cabreúva, visando custos mais baixos. Em 1984, a marca Vulcabras ganhou a condição de marca notória pelo Instituto Nacional de Propriedade Industrial. As aquisições quea Vulcabras fez de operações fabris em Franca foram motivadas pela elevada qualidade da mão-de-obra, obtendo os efeitos desejados. E m 1983, os irmãos Grendene adquiriram a Vulcabras, que detinha 5 fábricas, e várias licenças de marcas internacionais (MINADEO, 1992).

O s gêmeos Pedro e Alexandre G rendene iniciaram os negócios em 1972, produzindo embalagens plásticas para garrafões de vinho, na cidade gaúcha de Farroupilha. D epois, investiram nos calçados plásticos Melissa - um sucesso iniciado nos anos 80. Os irmãos separaram os negócios, ficando a Grendene com Alexandre (ficando Pedro com $20 \%$ de suas ações) e a Vulcabras com Pedro. A Grendene detinha as marcas Melissa e Ryder, com receitas de R \$1,1 bilhão em 2006, e 19,5 mil funcionários (CARVALHO, 2007). Em julho de 2007, a Vulcabras adquiriu 22,67\% do capital total da Azaleia. Em seguida, adquiriu 99,74\% das ordinánias. A holdingPilar Empreendimentos Imobiliários, que possuía 99,16\% das ações ordinárias da Azaleia, era das famílias De Paula eVolkart. O valorpago pelo controle foi de $\mathrm{R} \$ 342,388$ milhões (CO MPRA..., 2007). 
Kroehn (2007) afirma que 90\% da receita da Vulcabras é oriunda dos produtos Reebok, cujo contrato de 14 anos estava previsto para ser encerrado em 2012, o que abriria vulnerabilidade ao fabricante. A Vulcabras já passara por uma situação semelhante ao término de seu licenciamento com a Adidas - que adquirira mundialmente a Reebok em 2005. Assim, o autor situa a compra da Azaleia como uma ação defensiva, para proteger-se com a marca O lympikus a uma possível perda da licença da Reebok e manter-se no setor de esportivos. Houve uma evolução dessa situação, pois a Vulcabras fez um acordo com a Adidas, controladora da Reebok, para a distribuição dos artigos destaúltima no Brasil, até 2015 (VULCABRAS..., 2008).

A compra da Azaleia fez com que a Vulcabras não mais dependesse em $90 \%$ dos produtos da Reebok e ganhasse diversas novas marcas. Ao mesmo tempo, ingressou nas classes $\mathrm{C} \mathrm{e}$ D. Ao longo de um ano após a aquisição, o modelo de gestão da Vulcabras foi sendo implantado na Azaleia, calcado em a) busca por produtividade; b) controle de custos, e c) remuneração por resultados. A produção do tênis O lympikus foi transferida de Parobé (RS) e para Horizonte(CE), onde eram feitos os produtos Reebok; as unidades sergipanas, que apenas atuavam com a linha feminina, também começaram a produzir modelos esportivos. $O$ lançamento de coleções passou a ser mensal, ou até semanal. Cerca de $80 \%$ dos produtos passaram a regiões de mão-de-obra competitiva e incentivos fiscais. 0 tênis Olympikus passou a ser feito na fábrica argentina da Reebok - onde a carga tributária é 20\% inferior à do Brasil (FERREIRA, 2008).

A venda de uma empresa frequentemente é associada a uma derrota ou a um resultado negativo por parte do grupo vendedor. Mas, essa avaliação é simplista: no mundo empresarial, as estratégias precisam ser vistas de modo mais amplo, analisando-se todos os fatores envolvidos. Rigorosamente falando, a venda de uma empresa pode representar uma saída de um investimento com a realização de lucros - antes que a concorrênciavenha a se tornar mais acirrada, e a situação da empresa atinja um quadro irreversível. Desse modo, é preciso contextualizar a situação pela qual passava a Azaleia: o fundador sai de cena, e a súbita profissionalização do nível diretivo mais elevado da empresa se dá em um quadro de acelerada mudança nas condições ambientais pelas quais a empresa vinha passando: a queda das alíquotas de importação, a valorização cambial do real frente ao dólar, e o crescimento das exportações chinesas. Esses fatores minaram a lucratividade das exportações da empresa. Por outro lado, essa situação cambial auxiliou as empresas chinesas a ingressarem no Brasil, não sem antes se apoderarem de parte de nossos mercados no exterior.

Cabe destacar que a escolha de um ex-governador pelo próprio fundador da empresa para ser o seu sucessor é um fato elucidativo. McCann (1992) exemplifica com a Searle que nos anos 70 trocou toda sua equipe diretiva, substituindo-a por quadros egressos da administração pública, pois o FDA estava questionando uma série de testes toxicológicos da empresa. Assim, em meio a uma crise, a contratação dessa equipe possuía uma clara finalidade: conduzir a empresa com sucesso em meio às incontáveis negociações que seriam necessárias junto a diversas instâncias governamentais. Ora, ninguém melhor do que gestores públicos, com anos de experiência na burocracia federal, para conduzir esse processo. 0 autor acrescenta que coube a essa mesma equipe dirigir a difícil aprovação do aspartame para uso como adoçante, pois o FDA liberara a aprovação, porém, inesperadamente a retirou - havendo um período de vários anos até o produto retornar ao mercado.

Assim, na sucessão daAzaleia, poderia ter sido escolhido algum executivo com experiência comprovada em reestruturação e em direção de empresas. Cabe imaginar os motivos que levaram à escolha de um político. $\mathrm{O}$ u seja, talvez o principal papel desse sucessor fosse o de pilotar uma difícil etapa de transição, para uma futura decisão da família controladora - como ele declarou ao se retirar, ao final de 2006, tendo julgado cumprida a missão recebida. Além disso, o fato desse dirigente ter feito declarações públicas sobre os problemas criados pelas importações chinesas também pode sugerir que a possibilidade de obter tratamento público favorável a uma empresa brasileira com uma notável atuação social fosse uma das legítimas finalidades de sua indicação.

O ra, diante desse complexo quadro, a venda da empresa deve ser analisada no contexto de uma empresa de controle familiar, para quem o mesmo representa a maior parte de seu patrimônio. Assim, com a entrada de Britto, a profissionalização foi logo empreendida. D esse modo, tendo-se em conta que o setor calçadista é maduro e que nele são difíceis as inovações, e considerando-se o panorama global, as opções estratégicas mais evidentes pareceriam que:

a) A Azaleia poderia venderações em Bolsa de Valores, de maneira que os acionistas pudessem realizar parte de seus investimentos, e manter o restante das ações - de modo permanente ou para venda futura. E ssa opção teria a vantagem de diluir o risco de deixar todo 0 patrimônio familiar atrelado à companhia.

b) A empresa poderia empreender alguma aliança estratégica com outro grupo, de modo que os acionistas trocassem suas ações controladoras da Azaleia por uma posição de participação na nova empresa criada. Assim, por exemplo, sendo a Azaleia forte em calçados femininos, uma jaint-venturecom um grupo detentor forte em calçados masculinos ou em artigos esportivos poderia representar um fortalecimento dos dois grupos.

c) A empresa poderia aprofundar a reestruturação iniciada, de modo a se tornar mais atrativa para uma futura operação - que poderia vir a ser qualquer uma das duas acima apontadas.

O sacionistas perceberam que a profissionalização trouxe resultados, via corte de custos e venda de ativos secundários. A hipótese de ampliarem o escopo da estruturação parece impossível a um grupo ligado às famílias dos fundadores, e com inúmeros laços com funcionários antigos - ainda mais em uma empresa oriunda de uma pequena cidade, cuja economia é em grande parte representada pelos negócios da Azaleia. Além disso, a existência de um arrojado projeto ligado à responsabilidade social, acalentado desde 0 ano 2001, também parece indicar uma adicional dificuldade para que a própria empresa aprofundasse a reestruturação. Assim, uma solução que necessitasse de amplos

CONTEXTUS Revista Contemporânea de Economia e Gestão. Vol.8 - № 1 - jan/ jun/ 2010. (57-70). 
cortes de pessoal provavelmente não encontraria respaldo político nesse grupo de controladores - ainda que fosse fundamental para a competitividade da empresa, parecendo, portanto, bastante razoável buscar outras opções estratégicas.

A possibilidade de continuarem como controladores do negócio, porém, pareceria apresentar-se como sendo de elevado risco. Por exemplo, as dificuldades que a Olympikus enfrentou e continua enfrentando são enormes, dado que concorre com playessglobais - cuja produção é quase toda oriunda de países asiáticos de mão-de-obra barata. É com base nesse contexto que os resultados obtidos por essa marca nacional precisam ser aquilatados. Além disso, cabe ressaltar que a situação cambial não apresentava qualquer horizonte de reversibilidade - ou seja, o tempo atuava contra o futuro da organização, sendo bastante razoável supor o elevado grau de risco para a riqueza dos acionistas, representado pelo fato de deter uma grande parte de seus ativos atrelada ao difícil negócio de produção e exportação de calçados.

D ois eventos podem ter contribuído à decisão de venda da Azaleia: a) a Samello, uma das líderes nacionais em calçados masculinos, ejá em sua terceira geração, suspendera as atividades em outubro de 2006, segundo Gómez, Campassi e Mandl (2006), e b) Bueno (2007) afirma que a Reichert em poucos meses descontinuaria as atividades, demitindo todos os trabalhadores, ao redor de 4.600, em várias fábricas gaúchas, apesar de ter exportado no ano anterior US\$ 85 milhões - com 15,6\% de crescimento sobre 0 ano anterior. Bueno e Totti (2007) aduzem que a Reichert era a maior exportadora de calçados femininos do País, tendo respondido por 4,6\% das exportações brasileiras e a 6,8\% das exportações gaúchas de calçados de 2006 . 0 ra, duas renomadas empresas, de porte razoável e com forte tradição não sobreviveram ao ambiente global; pareceu natural aos controladores temerem pelo futuro da Azaleia. Assim, a venda pode ter representado a aceitação de uma proposta razoável, e com maior rapidez do que as três opções estratégicas acima apresentadas.

A venda da Azaleia representa um importante passo no contexto dos três tipos de crises vividas pelas empresas familiares apontados por Lodi. Houve a crise da saída de cena de um fundador carismático e centralizador; porém, seu trabalho de iniciar um processo de profissionalização logrou eliminar a segunda crise. Curiosamente, 0 amplo projeto social da empresa veio a ser 0 estopim da terceira crise - a da identidade - , 0 que contribuiu à venda do negócio.

0 grupo adquirente detém a marcaVulcabras, além de ser licenciado da Reebok e Ked's, reunindo as condições para garantir a possível continuidade da Azaleia. $O$ fato de dois irmãos controlarem, respectivamente, a Vulcabras e a $G$ rendene, faz vislumbrar uma possível fusão entre essas empresas, construindo um playernacional de porte global na produção de calçados. 0 fato de Pedro Grendene- controlador da Vulcabras - deter 20\% da $\mathrm{G}$ rendene reforça essa possibilidade. Além da força da marca Azaleia no mercado interno, um ativo importante para a decisão de adquinir foi tomado com base nas ações de internacionalização da empresa - como, por exemplo, a existência de uma rede de lojas, em parte próprias e em parte exclusivas, em vários mercados. A atuação de um fabricante de calçados no varejo significa a possibilidade de estar menos vulnerável à concorrência, pelo fato de possuir um canal de distribuição exclusivo para seus produtos, além do fato de contar com uma forma privilegiada de acompanhar a evolução do comportamento do consumidor.

\section{CONCLUSÕES}

A sucessão empresarial representa uma importante etapa que visa garantir a sobrevivência dos negócios, e que, no caso das empresas familiares, ganha importantes contornos pelo fato de elas representarem: a) parte importante do seu patrimônio; b) componentes históricos e afetivos de valor inestimável; c) memória viva do trabalho de pessoas queridas - pois os fundadores normalmente são da geração dos avôs ou dos pais, ou seja, unidos por inúmeros laços aos demais membros familiares, e d) possibilitarem oportunidades de trabalho aos membros das novas gerações.

0 estudo do processo sucessório da Azaleia foi rico, pois mostrou um planejamento em função da doença do seu fundador, que teve seis meses para preparar um sucessor. Pode não ter sido o ideal, porém, já apresenta algumas características de profissionalização - ainda mais que o sucessor apresentava um sólido histórico na vida política, e com algumas inserções no mundo empresarial.

A empresa em si mesma representa um conjunto interessante em realizações, tendo conseguido se tomar das maiores do mundo na produção de calçados femininos, além de manter suas bases culturais na cidade natal enquanto abria inúmeras novas unidades produtivas no Nordeste - cada vez mais importantes na proporção total da produção.

A sucessão foi iniciada com uma gestão profissional ortodoxa, por parte do sucessor - que chegou até o limite dos poderes a ele outorgados. Porém, a conjuntura do setor ao final de 2006 não permitia prever bons resultados ao setor calçadista nacional, inclusive ocorrendo duas perdas de certa forma irreparáveis: a quase centenária marca Samello - um verdadeiro sonho de consumo dos jovens de classe média dos anos 80 , com seu famoso dokkside- e a Reichert, uma grande exportadora de calçados femininos. Assim, a família resolveu pela vendaà Vulcabras, pertencente a dois irmãos que também controlam a $\mathrm{G}$ rendene. D esse modo, a sobrevivência do negócio fica mais fortalecida, ao mesmo tempo em que a família não teve de passar pelas dificuldades e pelos dilemas de um possível aprofundamento na reestruturação já empreendido - dado que os resultados de 2006 foram relativamente ruins, e sua reversão possivelmente exigiria medidas de maiores custos sociais.

A A zaleia detinha um projeto bastante amplo - ainda que criticado ou imperfeito - em responsabilidade social e acalentado pelo próprio fundador, o que pode ter impedido as familias controladoras de! implementarem maiores cortes, além de serem sem dúvida mal vistas na pequena localidade que acolheu a empresa e à qual eles certamente muito deviam. D essa forma, a venda do negócio representou uma saída que também levou em consideração essa vertente. 
As limitações do artigo estão devidas ao fato de que os dados secundários representaram a quase totalidade das fontes - o que não impediu, porém, a consecução dos objetivos propostos. Possíveis novos estudos sobre 0 tema das sucessões familiares podem contemplar estudos de casos múltiplos comparando-se companhias de setores diversos, ou situações variadas - como sucessões conflituosas. Além disso, a possibilidade de se usarem mais dados primários talvez traga maior riqueza de detalhes a esses estudos.

\section{REFERÊNCIAS}

AAKER, D. Administração Estratégica de Mercada Porto Alegre: Bookman. 1998.

ALVES, E.A.; FILHO, H. B. Reestruturação produtiva na indústria calçadista francana: expressões da precarização do ambiente fabril. In: SIMPÓ SIO DE ENG ENHARIA DE PRO DUÇÃ O, 12, 2005, Bauru. Anais Eletônicos.. Bauru. UNESP, 2005. D isponível em: $<$ http:/ / www.feb.unesp.br/dep/ simpep/Anais_XIISIMPEP/ 07.html>. Acesso em: 01 ago. 2007.

BALARIN, R. Algar investe na preparação de herdeiros. Valoronline, 21 set. 2007. Disponível em: <http:// www.valor.com.br>. Acesso em 21 set. 2007.

BARO NE, V. Azaleia cria A/ Z para equilibrar desempenho nas exportações. Valor online, São Paulo, 03 jul. 2006. D isponível em: $<$ http/ / :www.valor.com.br>. Acesso em: 01 ago. 2007.

BARROS, B. T.; HÉAU, D.; SOUZA, H. H. R. F.; STEUER, R. Fusões e aquisicốes no Brasil: entendendo as razões dos sucessos e fracassos. São Paulo: Atlas/ FD C, 2003.

BERNARDI, M. A. Lar, doce escritório. Patal Exame São Paulo, 15 jan. 1997. Disponível em: <http/ / :www.exame.com.br>. Acesso em: 01 ago. 2007.

BUENO, S. Azaleia fecha unidade no RS e demite 800 funcionários. Valor Online São Paulo, 06 dez. 2005a. Disponível em: <http/ / :www.valor.com.br>. Acesso em: 01 ago. 2007.

. Azaleia vende sua controlada ECCS para Brascan e retira-se do setor de energia. Valor Econômica São Paulo, 05 out. 2005b. D isponível em: <http:/ / www.valor.com.br>. Acesso em: 01 ago. 2007.

. Novas unidades farão Azaleia elevar capacidade em 30\%. Valơr Online, São Paulo, 08 mar. 2005c. Disponível em: <http:/ / www.valor.com.br>. Acesso em: 01 ago. 2007.

. Britto deixa o comando da Azaleia. Valor Online São Paulo, 05 dez. 2006. Disponível em: <http:/ / www.valor.com.br>. Acesso em: 01 ago. 2007.

. Para funcionários da Reichert, deixar cidade é alternativa. Valor Online, São Paulo, 30 mai. 2007. D isponível em: <http:/ / www.valor.com.br>. Acesso em: 01 ago. 2007.

BUENO, S.; TOTTI, P. Maior exportadora do Brasil de calçados fecha as portas. Valor Econômiøa São Paulo, 29 mai. 2007. Disponível em: <http:// www.valor.com.br>. Acesso em: 01 ago. 2007.

CAETANO, J. R. D a tumba para o pódio. Patal Exame, São Paulo, 24 jul. 1997. Disponível em: <http:/ / www.exame.com.br>. Acesso em: 01 ago. 2007.

CAMARG OS, D. 0 desafio de suceder lendas. Exame, v. 41, n. 18, ed. 902, p. 30-34, 26 set. 2007.

CANÇAD O, P. Pinheiro Neto traça novos rumos. O Estadb deSão Paulo Online, 10 dez. 2007. Disponível em: <http:// www.estadao.com.br>. Acesso em 10 dez. 2007.
CARVALHO, D. Dois irmãos contra a China. Patal Exame São Paulo, 26 jul. 2007. Disponível em: <http:/ / www.exame.com.br>. Acesso em: 01 ago. 2007.

CALO RI, R. \& al. Innovative International Strategies. Jamal of Wordd Business, v. 35, n. 4, 2000, p. 333-354.

CO MPRA da Azaléia custará R \$ 387,541 milhões à Vulcabras. Portal Exame, São Paulo, 01 ago. 2007. Disponível em: <http:/ / portalexame.abril.com.br/ negocios/ m0134984.html>. Acesso em: 02 ago. 2007.

COSTA, A. D. Sucessão e sucesso nas empresas familiares Curitiba: Juruá, 2006.

COSTA, A. J. D.; GARCIA, J. R. 0 empresário schumpeteriano e 0 setor de varejo no Brasil: Samuel Klein e as Casas Bahia. Reista de Economia, Curitiba, v. 32, n. 1, p. 57-82, jan./ jun. 2006.

CUNHA, L. Azaleia vai à China. IstoÉ Dinhero São Paulo, 21 dez. 2005. D isponível em:

<http:// www.terra.com.br/ isto edinheiro/ 432/ negocios/ azaleia_china.htm> Acesso em: 02 ago. 2007.

D 'AMBRO SIO, D. Calçadista adota loja própria para crescer no exterior. Valoronline, São Paulo, 12 jan. 2005. D isponível em: <http:/ / www.valor.com.br>. Acesso em: 01 ago. 2007.

O egípcio que veio decifrar o consumidor. Valor online, $\overline{2} 2$ out. 2007a. D isponível em: <http:/ / www.valor.com.br>. Acesso em: 22 out. 2007.

. Com gestão profissionalizada, Schin planeja investir $\overline{\mathrm{R}} \mathbf{1}$ bilhão em 2008. Valor anline 30 nov. 2007b. Disponível em: <http:/ / www.valor.com.br>. Acesso em 30 nov. 2007.

. J\&J escolhe executiva da casa para Presidência. Valor online 07 mar. 2008. Disponível em: <http:// www.valor.com.br>. Acesso em 07 mar. 2008.

DANTAS, V.; RACY, S. Cássio Casseb deixa presidência do Pão de Açúcar. O Estadb de São Paulo online, 11 dez. 2007. D isponível em: <http:// www.estadao.com.br>. Acesso em 11 dez. 2007.

DEIG HTON, J. How Snapple G ot Its Juice Back. Harvard Business Sdhool, Boston, v. 80, n. 1, jan. 2002. D isponível em: http:/ / hbswk.hbs.edu/ archive/ 2752.html>. A cesso em: 01 ago. 2007.

DIÓ G ENES, E. Administração - suas condicionalidades e fundamentos epistemológicos. Maceió, EDUFAL - Edit. Universidade Federal de Alagoas, 2007.

ED MONSON, G ail. Daimler Gives Chrysler to Cerberus. Business Wekk Online Red Oak, 14 mai. 2007.

ESTOL, K. M. F.; FERREIRA, M. C. O processo sucessório e a cultura organizacional em uma empresa familiar brasileira. RAC Reista de Administração Contemparânea, v. 10, n. 4, out-dez. 2006, p. 93-110.

FACCHINI, C.; BENICIO, R. Ponto Frio divide rede em lojas "pop" e sofisticadas. Valor online, 28 dez. 2007. D isponível em: <http:/ / www.valor.com.br>. Acesso em 28 dez. 2007.

FERREIRA, R. G. Azaleia no passo da Vulcabras. IstoÉ Dinhiron n. 562, 09 jul. 2008, p. 68-69.

FOSTER, R.; KAPLAN, S. Destruição Criativa. Rio de Janeiro: Editora Campus, 2002.

GASPAR, M. Os enrolados sócios da Petrobras. Exame, v. 41, n. 19, p. 108-110, 10 out. 2007.

GIL, A. C. Como daborar projetos de pesquisa São Paulo: Atlas, 1987. GIRION, L. A. Cia. Brasileira de Ilusões. Gazda Mecantili, Caderno de Fim de Semana, 05 jan. 2001, p. 1-2. 
GO MES, M. T. Azaleia. Potal Exame, São Paulo, 22 out. 1997. Disponível em: <http:/ / www.exame.com.br>. Acesso em: 01 ago. 2007.

GÓ MEZ, N. Azaleia diversifica linhas de produtos. Valor Econômica São Paulo, 18 jan. 2007. Disponível em: <http:/ / www.valor.com.br>. Acesso em: 01 ago. 2007.

GÓ MEZ, N.; CAMPASSI, R.; MAND L, C. Samello pede recuperação judicial. Valor Econônica São Paulo, 16 nov. 2006. D isponível em: <http:/ / www.valor.com.br>. Acesso em: 01 ago. 2007.

JO NES, G. Control, Performance and Knowledge Transfers in Large Multinationals: Unilever in the United States, 1945-1980. Working Knoweedge 12 set. 2002. Boston: Harvard Business School.

KANTER, R. M.; D RETLER, T. D. G lobal strategy and its impact on local operations: Lessons from Gillette Singapore. Academy of Management Exeative, v. 12, n. 4, p. 60-68, 1998.

KERIN, R. A.; VARAIYA, N. Mergers and acquisitions in retailing: a review and critical analysis. Joumal of Retailing v. 61, n. 1, p. 9-33, Spring 1985.

KROEHN, M. O grande passo dos Grendene. IstoÉ Dinheiro São Paulo, 12 jul. 2007. D isponível em: <http:/ / www.terra.com.br/ istoedinheiro/ edicoes/ 512/ artigo55753-1.htm?o=r>. A cesso em: 02 ago. 2007.

LIMA, M. G uimarães passa comando da Leão Júnior no fim do ano. Valor online, 25 out. 2007. D isponível em: <http:// www.valor. com.br>. Acesso em: 25 out. 2007.

MAGALHÃES, H. Andrade G utierrez entra na sua segunda fase de diversificação. Valor online, 30 nov. 2007. D isponível em: <http:/ / www.valor.com.br>. A cesso em 30 nov. 2007.

MANO, C. Galeazzi é o novo presidente do Pão de Açúcar. Patal Exame, 11 dez. 2007. D isponível em: <http:/ / www.exame.com.br>. Acesso em $11 \mathrm{dez} .2007$.

MARTINS, G.A. Estudb de casa uma estratégia de pesquisa. São Paulo: Atlas, 2006.

MATURO, J. Indústria de calçados agora aposta em marcas próprias. Valor Econômica São Paulo, 06 dez. 2004. D isponível em: <http:/ / www.valor.com.br>. Acesso em: 01 ago. 2007.

MARCOVITCH, J. Umpianero dbvargo modema Época Negócios, v. 2, n. 14, abr. 2008, p. 106-107.

MCCANN, J. E. Doce Suressa Rio de Janeiro: LTC, 1992.

MEYER, C. À procura de um presidente. Exame, v. 42, n. 3, 27 fev. 2008a, p. 22-30.

MEYER, C. Jonhson \& Jonhson já tem novo presidente. Patal Exame, 06 mar. 2008b. Disponível em: <http:// www.exame.com.br>. Acesso em: 06 mar. 2008b.

MINAD EO, R. Aquisiçôs de empresas motivações estratégicas e casos nacionais. 1992. 314f. D issertação (Mestrado em Administração) - CO PPEAD/ UFRJ, Rio de Janeiro, 1992.

MINAD EO, R. Classificação e análise de processos sucessánios. In: SEMEAD, 8. São Paulo: FEA-USP, 2008.

NAIDITCH, S. D epois que o dono se vai. Patal Exame, São Paulo, 25 mai. 2004. Disponível em: <http:/ / www.exame.com.br>. Acesso em: 01 ago. 2007.

NAID ITCH, S. Em busca do brilho próprio. Exame, v. 41, n. 18, ed. 902, p. 24-29, 26 set. 2007.

NAKAMURA, P. Lucro da Azaleia cresceu 62,8\% no ano passado. Valor Econônico São Paulo, 14 mar. 2007. D isponível em: <http:/ / www.valor.com.br>. Acesso em: 01 ago. 2007.
NETO, A. B.; MO REIRA JR., A. L. Difiauldades para a realização da sucessãa um estudo em empresas familiares de pequeno porte. In: SEMEAD, 5. São Paulo: FEA-USP, 2001.

NÓ BREGA, C. E no Brasil... O s mesmos males (e sua cura). Época Negóios dezembro de 2007, p. 68-69.

ONAGA, M. Agora começa a fase dois. Exame, v. 41, n. 908, 13 dez. 2007, p. 68-70.

PERERA, L. C. J. \& al. Aquisição como instrumento de vantagem competitiva - estudo de caso: aquisição da Ripasa. In: ENCONTRO DE ESTUDOS EM ESTRATÉGIA, 3, 2007, São Paulo. Anais Eletrônicos.. São Paulo: ANPAD, 2007. CD-ROM.

PIMENTA, D. P; BORGES, J. F. A condução do processo sucessório de uma empresa como competência do empreendedor. In: ENCONTRO ANUAL DA ASSOCIAÇÃO NACIONAL DOS CURSOS DE GRAD UAÇÃO, 16, 2005, Belo Horizonte. Anais Eletrônicos.. Rio de Janeiro: ANG RAD, 2005. CD -ROM.

REESTRUTURAÇÃO na Gerdau. Portal Exame, 20 set. 2007. D isponível em: <http:/ / www.exame.com.br>. Acesso em: 20 nov. 2007.

RIBEIRO, F. C. F.; JÚNIOR, M. M. O. Transferência e transferência reversa de conhecimento em aquisições internacionais: 0 caso da aquisição da Perez Companc pela Petrobras na Argentina. In: ENCONTRO DE ESTUD OS EM ESTRATÉGIA, 3, 2007, São Paulo. Anais Elerônicos.. São Paulo: ANPAD, 2007. CD-ROM.

RIBEIRO, M. S. A responsabilidade so cial como estratégia da atividade de relações públicas: caso Indústria de Calçados Azaleia. In: Congresso Brasileiro de Ciências da Comunicação, 26, 2003, Belo Horizonte. Anais Elerônicos.. Belo Horizonte: INTERCO M, 2003. D isponível em: <http:/ / www.fca.pucminas.br/ saogabriel/ comorganizacional/ textos_novos_24_05_07/ relacoes_publicas/ responsabilidade_social.pdf $>$. A cesso em: 02. ago. 2007

ROBERT, M. Estratégja: Como Empresas Vencedoras Dominam Seus Concorrentes. São Paulo: Negócio Editora, 1998.

ROCHA, R. E. V.; VIANA, F. L. E. Análise da competitividade da Indústria de Calçados da Região Nordeste. In: SIMPÓ SIO DE ENGENHARIA DE PRODUÇÃO, 13, 2006, Bauru. Amais Eletrônicos... Bauru. UNE SP, 2006. D isponível em: <http:/ / www.feb.unesp.br/ dep/simpep/Anais_XIII/ index.html>. Acesso em: 01 ago. 2007.

ROSENBUSH, S. When Big Deals Go Bad - and Why. Business Wek Online, 04 out. 2007. Disponível em: <http:// www.businessweek.com>. Acesso em: 05 out. 2007.

RO SSETI, J. P. Fusões e aquisições no Brasil: as razões e os impactos. In: BARRO S, B. T. (O rg.). Fusões aquisiçoes \& parcerias São Paulo: Atlas, 2001. p. 67-87.

SCHENKER, J. L. Italiana Geox entra no mercado de tênis de corrida. Valor online, 11 abr, 2008. Disponível em: <http:/ / www.valor.com.br>. Acesso em 11 abr. 2008.

SERRA, F. A. R.; CO STA, L. S. V.; FERREIRA, M. P. Estudo de caso em pesquisa de estratégia: aspectos fundamentais de projeto de investigação. Revista ANGRAD, v. 8, n. 2, abr.-jun. 2007, p. 169182.

SO BRAL, E. A difícil missão de suceder Sílvio Santos no comando do SBT. Valor online, 14 nov. 2007. D isponível em: <http:/ / www.valor.com.br>. Acesso em 14 nov. 2007.

SPOTORNO, K. Confiança e credibilidade não se compram. Época Negóios dezembro de 2007, p. 192.

SVEIBY, K. E. A nova Riqueza das Organizaçōes. Rio de Janeiro: Campus. Terceira Edição. 1998. 
ULLER, R. Profissionalização na empresa familiar: 0 caso da Perdigão Agroindustrial S/ A. 83f. D issertação (Mestrado em Engenharia de Produção). Florianópolis: UFSC, 2002.

VERGARA, S. C. Progitos erdatónios de pesquisa emadministraçãa São Paulo: A tlas, 1997.

VULCABRAS torna-se sócia da Reebok no Brasil. Patal Exame, 25 mar. 2008. D isponível em: <http:/ / www.exame.com.br>. Acesso em: 28 mar. 2008.

WALTER Fontana deixa conselho da Sadia, Furlan retorna. Valor Online, 06 out. 2008. D isponível em: <http:/ / www.valor.com.br>. Acesso em 06 out. 2008.

WRIGLEY, N. Strategic market behaviour in the internationalization of food retailing: interpreting the third wave of Sainsbury's US diversification. European Journal of Marketing v. 34, n. 8, 2000, p. 891-918.

YIN, R. K. Estudb de casa planejamento e métodos. Porto Alegre: Bookman, 2005.

ZOOK, C.; ALLEN, J. Lucro a partir do core business - estratégias rentáveis de crescimento. Rio de Janeiro: Campus, 2001.

Data de Submissão: 16/ 06/ 2008

Data de Aprovação: 10/ 08/ 2009 
